\title{
LESSON STUDY STRENGTHENING TRAINING FOR YOUNG LECTURERS TO IMPROVE LECTURE QUALITY
}

\author{
Martono $^{1)}$, Hairida ${ }^{2)}$, Erwina Oktavianty $\left.{ }^{3 *}\right)$, Reni Marlina ${ }^{4)}$, Hemri Yansa ${ }^{5)}$ \\ ${ }^{1)}$ Pendidikan Bahasa Indonesia, Fakultas Keguruan Ilmu dan Pendidikan Universitas Tanjungpura \\ 2)Pendidikan Kimia, Fakultas Keguruan Ilmu dan Pendidikan Universitas Tanjungpura \\ ${ }^{3)}$ PendidikanFisika, Fakultas Keguruan Ilmu dan Pendidikan Universitas Tanjungpura \\ 4)Pendidikan Biologi, Fakultas Keguruan Ilmu dan Pendidikan Universitas Tanjungpura \\ 5) Fakultas Keguruan Ilmu dan Pendidikan Universitas Tanjungpura \\ Jalan Profesor Hadari Nawawi Pontianak, Kalimantan Barat
}

Corresponding : erwina.oktavianty@teacher training institution.university.ac.id

\begin{abstract}
This article aims to describe the implementation of socialization activities and technical guidance for the implementation of Lesson Study for young lecturers in the Faculty of Teacher Training and Education, Tanjungpura University (University) and to explore information about participants' opinions on the implementation of lesson study in lectures. Opinions were obtained from the stages of socialization and technical guidance on the implementation of the learning quality improvement program through Lesson study. This activity is carried out in two stages. Phase 1 is a field orientation activity carried out by the team, the purpose of this activity is to prepare activities and collect data on young lecturers (CPNS) who are in the teacher training institution at university environment. Phase 2 is a lesson study cycle socialization and technical guidance activity which was carried out in a 4-hour meeting on 27 July 2020 at the teacher training institution University. In this activity, 4 team members as resource persons were present to provide strengthening of lesson study to participants in the socialization and technical guidance, besides that this activity was also attended by 29 participants who were young lecturers in the faculty. With these stages, it is hoped that this community services activity can produce an understanding of sustainable programs for young lecturers in order to improve the quality of professional lecturers and can improve the quality of learning so that it results in increased results and learning processes for students. So that in the end it can build a learning community that affects the improvement of the quality of education.
\end{abstract}

\section{Keyword: Lesson Study, Young Teachers, Community Services}

\section{INTRODUCTION}

Preparation of Human Resources

(HR) through formal education providers faces tremendous challenges during advanced science and technology development. Education at this time caused a change in the educational paradigm, namely a change in mindset and behavior.
The National Education Standards stated in the Government Regulation of the Republic of Indonesia Number 19 of 2005 state that: (1) The learning process in academic units is carried out interactively, inspiring, fun, challenging, motivating students to participate actively, and providing sufficient space for the initiative, creativity. And 
independence according to the talents, interests, and physical and psychological development of students. (2) In addition to the provisions as referred to in paragraph (1), in the learning process, educators provide an example. (3) Each academic unit shall plan the learning process, implement the learning process, assess learning outcomes, and supervise the learning process to implement an effective and efficient learning process. Therefore, both teachers and lecturers must be more creative and innovative in improving the quality of educational services, especially learning process services, following process standards (Permendiknas number 41 of 2007). The professional teaching staff is reflected in teaching students, making students active and creative, and learning is practical and makes students happy. For this reason, the learning process needs to be planned, implemented, assessed, and monitored in order to be carried out effectively and efficiently.

The Faculty of Teacher Training and Education, University of Tanjungpura as an educational institution is responsible for improving the quality of learning by producing professional human resources for teachers. It is under the goals of national education, the goals of national education stated in Law No. 20 of 2003, namely developing the potential of students to become human beings who believe and are devoted to God Almighty, have a noble character, are healthy, knowledgeable, capable, creative, independent and become a democratic and responsible citizen in the context of the intellectual life of the nation, can be achieved. In 2005 the government had a legal umbrella in improving the quality of education by issuing Law No. 14 concerning Teachers and Lecturers, which demanded adjustments to the implementation of education and coaching of teachers and lecturers as a profession. Recognition of teachers and lecturers as professionals will be given when the teachers and lecturers have the required academic qualifications, competencies, and educator certificates (Article 8). The types of competencies referred to in the Act include pedagogic competence, personality competence, social competence, and professional competence (Article 10 paragraph (1)). Another effort to improve the quality of the implementation of academic education is to improve/revise the curriculum following the Indonesian National Qualifications Framework (KKNI, Presidential Decree No. 8 of 2012), followed by improving the quality of learning in line with the Student-Centered Learning (SCL) approach.

However, the learning carried out still shows students who feel bored even though they seem engrossed in listening to information from the lecturer in the lecture 
process. The questions asked by students are still one-way, so that students do not get the opportunity to discuss challenging issues with their friends. Such lecture activities continue not to get critical thinking, collaboration, creativity, and communication. Whereas every student has the right to learn, has the right to be served well, has the right to be facilitated to learn from each other. Learning that is not fun and challenging for students will not inspire selfdevelopment to create jobs for themselves or others in the future. In other words, in turn, such learning cannot create skilled workers.

The demand to create quality human resources capable of facing changes and current global competition has become urgent. Therefore, professional educators (teachers and lecturers) are needed who can create a quality education system and create a learning atmosphere that can facilitate students to develop themselves into creative and highly competitive human beings and democratic and of good character. In order to achieve this, it is necessary to establish a system to learn from each other from all parties through lesson study in a learning community or known as the Learning Community.

Masaaki (2012) added that the nature of children's learning at school is getting knowledge from the teacher and interaction and learning together with friends. One strategy that can be applied to achieve this is a collaborative learning strategy. Ueno (2013) explains that in Collaborative Learning, teachers design learning to students that can learn from each other. In Collaborative Learning, teachers also need to provide materials and media that support collaborative learning activities, provide questions or assignments that encourage exploration, and students work in study groups (Sato, 2012).

The importance of "learning from others" experiences and real experiences of how other people do learning has often been expressed in various works of literature. Several studies that have been conducted have shown that teachers are challenging to change (Davis, 2003) and that studentteacher candidates learn more from how they are taught by their lecturers and not from what is explained by lecturers about suitable teaching methods (Mellado, 1998). Because lesson study is a source of real examples of how to do learning, participation as an observer in lesson study or watching video recordings of lesson study can improve teachers' teaching abilities and prospective teacher students. Ueno (2013) suggests that lesson study does not prioritize solving problems and difficulties but instead sharing problems, interacting, and thinking to solve problems together. Yasuo (2013) also added that universities need to build collegiality with teachers in carrying out the 
duties and skills of the teaching profession through lesson study.

Teacher training institution has had experience in implementing Lesson Study since 2009 in the LEDIPSTI Lesson Study Batch 1 program in 2009 for three years in the Department of Mathematics and Natural Sciences (MIPA). Then, the implementation of the Lesson Study was distributed and continued independently by lecturers in the science education department. The expansion of Lesson Study through the Mathematics and Natural Sciences Education Department, Faculty Education and Teacher Training, Tanjungpura University, showed significant development. By carrying out Lesson Study, lecturers become more aware of students' learning problems. They share experiences about implementing lectures with fellow lecturers in a group/clump of fields of science or across fields of science. Thus, there is an openness and an increase in the accountability of lectures carried out by lecturers. In the lecture planning discussions concerning preparing lesson plans, teaching materials, and learning tools, there has been a direct transfer of knowledge from one lecturer to another. Lesson study activities can encourage many parties to do their best in improving the quality of lectures in universities or improving the quality of learning in schools.
The implementation of the lesson study is still ongoing at the LPTK (teacher training institution) University. However, it is deemed not optimal because more senior lecturers dominate it. It is necessary to expand the implementation of lesson study for the learning community for new lecturers in the teacher training institution's environment. It based on the consideration that Faculty of Education and Teacher Training, University of Tanjungpura in 2019 accepted 34 prospective Civil Servant lecturers in several study programs. The potential possessed by these young lecturers will be very optimal if a collaborative and sustainable learning assessment is carried out so that improving the quality of learning can be carried out through a learning community within the teacher training institution at university as a center for educational reform in the context of increasing teacher professionalism. The reformed center developed is expected to become a model for reformist study programs that can be used as good examples for study programs or even schools that carry out lesson studies in improving the professionalism of their teachers on an ongoing basis.

Through Lesson study, it is hoped that in the end, it can improve the professionalism of young lecturers and ultimately have a significant impact on improving the quality of education in 
general and the formation of a learning community. Based on the description above, it is necessary to capture the participants' perceptions to see the effectiveness of the training in lesson study activities for young lecturers in the pre-service teacher institution's environment in implementing lesson study-based learning, especially open class and reflection learning. This is done to have a model of sustainable teachers for young lecturers to improve the quality of professional lecturers. Building a learning community that affects improving the quality of education - finding a model of a pilot study program that applies lesson study and can be used as an example of a reformist school in sustainably developing professional teachers.

\section{METHOD}

The method of implementing socialization activities and technical guidance as a Community Service program is orientation and training. In both stages, the activities carried out were the team's orientation of community services activities to partners, determining several young lecturers to be model lecturers in partner study programs: socialization and technical guidance on implementing lesson study to participants. Then after the socialization and training activities, the participants were given a survey aimed at digging up information on the participants' responses to the socialization activities and providing technical guidance for implementing the lesson study. An online questionnaire was used in this study with 20 questions.

\section{RESULT AND DISCUSSION}

The implementation of Community Service Activities aims to socialize lesson study activities and provide technical guidance for its implementation to young lecturers in the teaching institution at the University of Tanjungpura. Therefore, it is hoped that the study of lectures through lesson study can continue through new lecturers in the Faculty of Education's environment in implementing lesson studybased learning, incredibly open classes, and learning reflection. This activity is carried out in three stages.

Phase 1 is a field orientation activity carried out by the team; this activity aims to prepare activities and collect data on young lecturers in the university's environment. Based on this orientation activity, data obtained from lecturer's candidates in the university's environment amounted to 34 people.

The next stage was stage 2; at this stage, socialization activities and lesson study cycle guidance are carried out in a 4hour meeting on 27 July 2020 at the Faculty's Hall. In this activity, four team members were present to reinforce lesson 
study to participants in the socialization and technical guidance. Each resource person provides Strengthening Lesson Study, Lesson Study Philosophy, Collaborative Learning, Learning Analysis through learning transcripts.

\section{Response to Lesson Study Implementation}

The response of the participants was obtained based on a questionnaire distributed online via a google form. Participants who filled out the questionnaire were representatives of the four departments in the teaching and education faculty, as shown in figure .

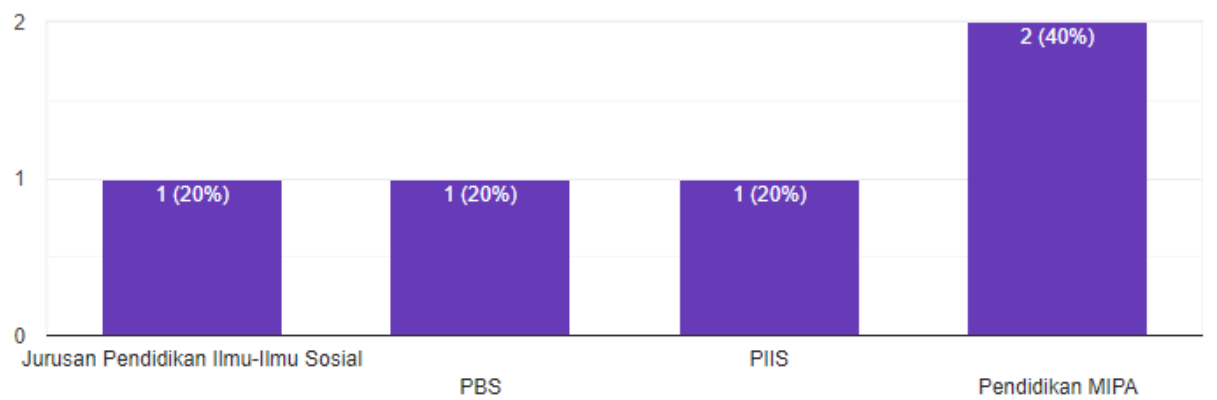

Figure 1. Majors of Participants Participating in the Questionnaire.

\section{Participants' responses were} explored in several aspects, namely how lesson study helps teachers and lecturers have mastery of the material (A1), the use of learning media (A2). Lesson study helps teachers both in planning assessments to conducting authentic assessments (A3), lesson study helping teachers in manage learning to be more effective (A4) and involve students actively in learning (A7). For example, lesson study provides an opportunity for teachers to become better and as role models for students (A6). Communication built both in learning and outside learning becomes better through the lesson study process (A5). The questionnaire was analyzed from the participant's responses to each of the above aspects. The scale used in the questionnaire is strongly agreed, agree, disagree, strongly disagree. The perception of the training participants can be seen in the graph below. 


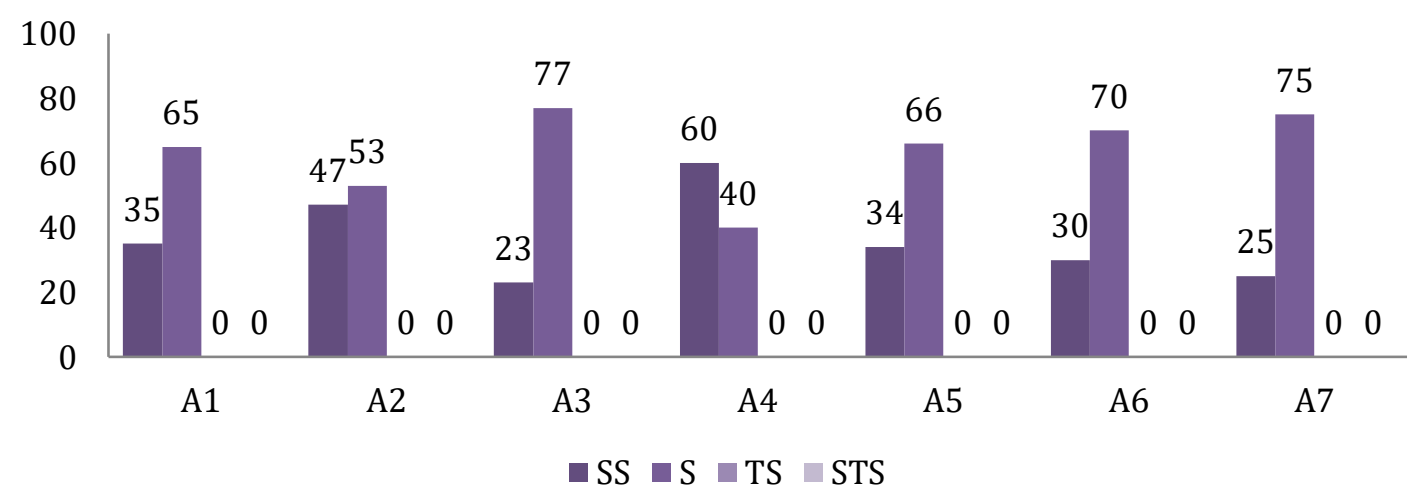

Figure 2. Perceptions of Participants in Socialization and Training on Learning Based on Lesson Study (in percentage).

Based on the data above, information was obtained that participants agreed that learning managed through a lesson study approach could improve the skills of teachers or lecturers in teaching. As Haratua et.al (2011) said lesson study can improve the quality of teaching and learning on Nuclear Physics Lecture. Based on the results of Nuclear Physics Lectures, the percentage of students achievement was increased $29,5 \%$, from $49,25 \%$ to $78,75 \%$. The increasing of the learning mastery concept because lesson study activities give a chance for the teacher to plan the lecture collaboratively with colleague. collaborative learning can improve the quality of the learning process (Sato, 2013). It allows team teaching learned about the students and the need of the lectures effectively from others. This is in line with what Rozak, et al (2013) said that the implementation of lesson study has a positive impact on the development and improvement of the pedagogical competence of Indonesian language teachers. After following the lesson study, the teacher has adequate ability in designing lesson plans. In addition, the application of lesson study in environmental knowledge courses based on local excellence has also improved the quality of biology learning, significantly improving life skills (Yokhebed et al., 2016).

In addition to making excellent lesson plans, carried out collaboratively with lesson study activities, assessment is also the focus of activities based on lesson study. Respondents agreed that Lesson study helps teachers plan assessments to conduct authentic assessments (A3). The highest percentage, they believe teachers and lecturers can plan and carry out assessments, especially authentic assessments, reaching $77 \%$. It is in line with Norwich, B and Ylonen, A (2014), teachers that involved in the lesson study activities agreed a set of 
assessment-related outcome statements, e.g. a renewed interest in in-depth assessment, better understanding of learning needs and more capability to use of response to teaching approach to assessment. Lesson study has three main steps; as Dudley (2014) says, Lesson Study consists of a cycle of three research lessons, which are jointly planned, taught by one of the team, and directly observed by the rest of the team. In this version (there are other versions, too), the teams identify one to two pupils as the focus for the planning and evaluation. These case pupils are identified depending on the topic and aims of the Lesson Study.

In addition, good communication and role models can be obtained through good habits in the learning community process. In lesson study, the planning process to learning evaluation is carried out collaboratively.

\section{CONCLUSION}

Based on the achievements of the service results carried out above, it can be concluded that the services program is running well but still needs to be continued as a collaborative program between majors in faculty. It is hoped that after the community service activities, the faculties will form a learning community on an ongoing basis so that learning problems carried out by teachers can be overcome based on the lessons learned by young lecturers and other colleagues through observation and reflection on learning.

\section{REFERENCES}

Brahm Norwich \& Annamari Ylonen (2015): A design-based trial of Lesson Study for assessment purposes: evaluating a new classroom based dynamic assessment approach, European Journal of Special Needs Education, DOI:

10.1080/08856257.2015.1009702

Depdiknas, 2003. Undangundang Sistem Pendidikan Nasiona 1. (Online). http:// www.dikti.go.id/files/atur/U U202003Sisdiknas.pdf, diakses pad atanggal20Agustus2012).

Dudley, P. (2012). "Lesson Study Development in England: From School Networks to National Policy." International Journal for Lesson and Learning Studies 1 (1): 85-100.

Haratua TMS., Erwina Oktavianty, Hamdani,. 2011. Implementasi lesson study untuk meningkatkan kualitas perkuliahan fisika inti. Jurnal Pendidikan Matematika dan IPA. Vol 2 no 1. Pontianak: TEACHER TRAINING INSTITUTION University

Hendayana, S dkk, 2006, Lesson Study: Suatu Strategi untuk meningkatkan keprofesionalan Pendidik. Bandung: UPI Press

Kemendikbud. 2013. Kurikulum 2013, Kompetensi Dasar Jenjang Sekolah Menegah Atas (SMA)/Madrasah Aliyah (MA).Jakarta

Mercer, N \& Littleton, K. (2007). Dialogue and The Development of Childrens 
Thinking. New York : Routledge.OECD. 2018

Permendiknas nomor 41 tahun 2007. Standar Proses Untuk Jenjang Pendidikan Dasar dan Menengah. Jakarta. Menteri Pendidikan Nasional.

Permendikbud Nomor 81A Tahun 2013 tentang Implementasi Kurikulum.

Permendikbud RI, 2016, Standar Proses (Online) (http://bsnp-indonesia.org, diakses pada tanggal 30 Januari 2017)

Permendikbud RI, 2016, Standar Isi (Online) (http://bsnp-indonesia.org, diakses pada tanggal 30 Januari 2017)

Raharjo, Kurniawan Budi. 2013. Model Pembelajaran Kolaborasi (Collaborative Learning). (online) (diakses pada 25 agustus 2020).(https://kurniawanbudi04.wo rdpress.com/2013/05/27/collaborati ve-learning/)

https://www.jogloabang.com/pendi dikan/pp-19-2005-standarnasional-pendidikan

Rozak, Abdul and Fauziah, Eva. (2013). Implementasi Lesson Study Sebagai Upaya Peningkatan Kompetensi Pedagogik Guru Bahasa Indonesia Di SMP Kabupaten Cirebon. Jurnal Pendidikan Bahasa dan Sastra. Vol 12 Nomor 01. Bandung : Pendidikan Bahasa dan Sastra, UPI Bandung.
Sato, M. (2012). Mereformasi Sekolah : Konsep dan Praktek Komunitas Belajar. Tokyo International Development Center of Japan. Inc.

Sato, Masaaki. 2012. Dialog dan Kolaborasi di Sekolah Menengah Pertama, Praktek "Learning Community". Jakarta: Pelita

Ueno, Masamichi. 2013. Pembelajaran Kolaboratif dan Pendidikan Demokrasi.Makalah Disajikan pada Short-Term Training on Lesson study (STOLS) for Institute of Teacher Training and Education Personnel (ITTEP), Tokyo, 14 Oktober-8 November.

Yasuo, Shoji. 2013. Peran Perguruan Tinggi dan Peneliti (Akademisi) Dalam Lesson study Serta Kerjasama Dengan Pihak Pemerintah.Makalah Disajikan pada Short-Term Training on Lesson study (STOLS) for Institute of Teacher Training and Education Personnel (ITTEP), Tokyo, 14 Oktober-8 November.

Yokhebed. 2016. Peningkatan Kecakapan Hidup Melalui Pembelajaran Berbasis Keunggulan Lokal Pada Calon Guru Biologi. Prosiding Seminar Nasional Biologi XIII "Biologi, Sains,Lingkungan dan pembelajarannya" Surakarta, 6 Agustus 2016. 